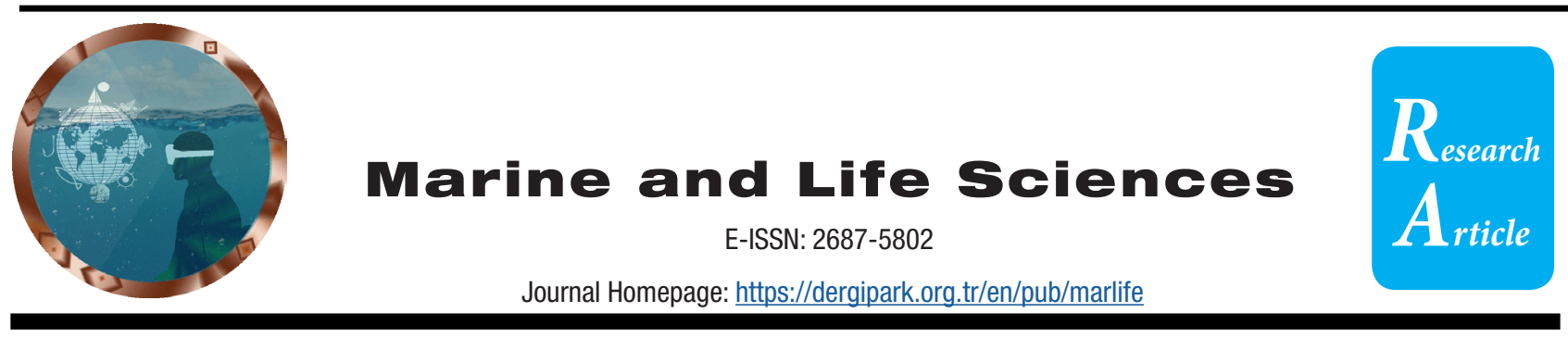

Case-based HFACS analysis of Ro-Ro ship accidents

\author{
Eșref Can Demirci' ${ }^{1 *}$, Seçil Gülmez ${ }^{2}$
}

*Corresponding author: esref.demirci@iste.edu.tr

Received: 24.11.2021

Accepted: 18.12.2021

\begin{abstract}
Affiliations
${ }^{1}$ Iskenderun Technical University, Maritime Vocational School, Institute of Graduate Studies, Iskenderun, Hatay, TURKEY

${ }^{2}$ Iskenderun Technical University, Barbaros Hayrettin Naval Architecture and Maritime Faculty, Iskenderun, Hatay, TURKEY
\end{abstract}

\section{Keywords}

Maritime transportation

Ro-Ro ships

Ship accidents

Accident reports

HFACS

\section{ABSTRACT}

The aim of this study is to determine the types of marine accidents caused by human error on Ro-Ro Cargo ships and to analyze the usefulness of the Human Factors Analysis and Classification System (HFACS) method in classifying these accidents. In this context, 30 different Ro-Ro ship accident were examined and the human factors causing the accident were determined. The causes of these accidents were evaluated with a focus group study which was held with 6 experts and coded according to levels and criteria of HFACS. With this classification, human error rates that cause accidents were determined.

\title{
Ro-Ro gemi kazalarının vaka bazlı HFACS analizi
}

\author{
Anahtar Kelimeler \\ Denizyolu tașımacılığı \\ Ro-Ro gemileri \\ Gemi kazaları \\ Kaza raporları \\ HFACS
}

\section{ÖZET}

Bu çalıșmanın amacı, Ro-Ro yük gemilerinde insan hatalarının sebep olduğu deniz kaza türlerinin tespiti ve bu kazaların sınıflandırılmasında İnsan Faktörleri Analiz ve Sınıflandırma Sistemi (Human Factors Analysis and Classification System-HFACS) yönteminin kullanıșıı̆ı̆ının analiz edilmesidir. Bu kapsamda 30 farklı Ro-Ro gemi kazası incelenmiș, kazaya sebebiyet veren insan faktörleri tespit edilmiștir. Kaza sebepleri, 6 uzman ile birlikte gerçekleștirilen odak grup çalıșması ile değerlendirilerek HFACS düzey ve kriterlerine göre kodlanmıștır. Yapılan bu sınıflanma ile birlikte kazalara sebebiyet veren insan hatalarına ait hata oranları tespit edilmiștir.

\section{Giriș}

Denizyolu tașımacılığı sırasında gemi kazaları sanılanın aksine oldukça sık yașanmakta olup, kazaların sonuçları maddi, manevi ve çevresel açıdan büyük olumsuzluklara yol açmaktadır. Deniz kazası denilince akla sadece iki geminin çatıșması gelse de aslında birbirinden farklı birçok kaza türü bulunmaktadır. Bunlardan bazıları, karaya oturma, yangın, batma/su alma, gemi ekipman hasarı ve gemi iș kazalarıdır. Deniz kazaları aynı zamanda az ciddi kazalar, ciddi kazalar ve çok ciddi kazalar olarak da kendi içinde sınıflandırılmaktadır (IMO, 2000; MSC-MEPC, 2000). Deniz kazaları gemi türlerine göre de farklılık göstermektedir. Bunun nedeni farklı gemi türlerinin sahip oldukları farklı özellikler sebebiyle kazalara sebebiyet verecek nedenlerin değișkenlik gösterebilmesidir (Chen ve ark., 2019). Geminin yașı, yapısal özellikleri, kalitesi gibi durumlar kaza sıklığını etkilemekle 
birlikte, yapılan çalıșmalar gemi türü olarak yolcu gemileri arasında kurvaziyer gemilerinde kaza sıklığının, Ro-Ro yolcu gemilerinde ise ölümlü kaza oranlarının yüksek olduğunu göstermektedir (Wei ve ark., 2015; Eliopoulou ve ark., 2016). Örneğin; yolcu gemisi kazalarının sonuçlarının diğer gemi kazalarına göre daha yıkıcı olması nedeniyle ayrıca değerlendirilmiș ve kaza nedenleri ortaya koyulurken bu gemi türüne özel durumlar göz önüne alınarak çalıșmalar yapılmıștır (Yıldız, 2016). Benzer bir örnek ise tehlikeli madde tașıyan tanker gemilerinde meydana gelen yangın ve patlama kazaları için söz konusudur (Uğurlu, 2016). Bu nedenle deniz kazaları incelenirken gemi türleri ve özellikleri de dikkate alınmalıdır. Deniz kazaları her yıl raporlanarak, gemi tipine göre dağılımları verilmektedir (JTSB, 2020; TSB, 2020).

Gemide emniyetin sağlanması için Uluslararası Denizcilik Örgütü (International Maritime Organization-IMO) tarafından bir dizi kural ve sözleșme olușturulmuștur. Bunlardan en önemlisi, Denizde Can Emniyeti Uluslararası Sözleșmesi (International Convention for the Safety of Life at Sea-SOLAS) konvansiyonudur. SOLAS'ın kapsamı gemilerin inșası, ekipmanı ve yönetimi ile ilgili minimum standartları belirlemektir. Bir diğeri, denizlerin gemiler tarafından kirletilmesini önleyerek çevresel risklerin azaltımasını hedefleyen sözleșme Denizlerin Gemiler Tarafından Kirletilmesinin Önlenmesine Ait Uluslararası Sözleșme (The Convention on the Prevention of Maritime Pollution-MARPOL)'dir. Bunun yanında, ticari gemilerde emniyetle ilgili tüm kurallara rehberlik eden Uluslararası Emniyet Yönetimi (International Safety Management-ISM) kodu IMO tarafından zorunlu tutulmaktadır. Denizde Çatıșmayı Önleme Tüzüğü ise (The International Regulations for Preventing Collisions at SeaCOLREG) deniz trafiğinin düzenlenmesi ve deniz trafiğinde uyulması gereken kurallarla ilgilidir. Tüm bu kurallara uyulması deniz kazalarının önlenmesinde öncelikli önem tașımaktadır. Gemide yapılan her bir operasyon için uyulması gerekli kurallar bellidir ve uyulmadığı süreçte kaza meydana gelmemesi tamamen șanstır (Akyüz, 2015).

Deniz kazalarını konu alan çalıșmalar farklı gemi türlerinde gerçekleșen gemi kazalarını çeșitli perspektiflerden incelemișlerdir. Navas de Maya ve Kurt (2020) ise genel kargo gemilerinde deniz kazalarına sebep olan insan ilișkili sebepleri bulanık bilișsel haritalandırma yöntemi ile incelemiștir. Arslan ve ark. (2018) tanker gemilerinde yükleme boșaltma operasyonlarında meydana gelen kazaları analiz etmișlerdir. Sarıalioğlu ve ark. (2020) yolcu gemilerinde makine dairesi yangınlarını HFACS-PV yaklașımı ile ele almıștır. Benzer șekilde Kaptan ve ark. (2021) tanker gemilerinde teknoloji kullanımında karșılașılan uygunsuzlukların deniz kazalarına etkisini HFACS-PV perspektifinde araștırmıștır. Wei ve ark. (2015) ise Ro-Ro tipi yolcu gemilerde meydana gelen kazalarda insan faktörünü HFACS-El yaklașımıyla incelemiștir. Mevcut çalıșmalar dikkate alındığında Ro-Ro tipi yük gemilerinde meydana gelen kazalarda insan faktörünün incelendiği çalıșmaların görece sınırlı olduğu gözlemlenmiștir. Ayrıca literatür bulguları doğrultusunda HFACS perspektifinin bu gemi türlerinde meydana gelen insan faktörünün bulunduğu kazaları sınıflandırmada yeterli olup olmadığına yönelik bir çalıșma da tespit edilmemiștir. Yük türündeki farklılıkların kaza sebeplerini farklılaștırmadaki etkisi dikkate alındığında bu çalıșma kapsamında așağıda belirtilen araștırma soruları belirlenmiștir:

1. Ro-Ro tipi yük tașıyan gemilerde insan hatalarından kaynaklı kaza türleri nelerdir ve kaza sebepleri nasıl bir dağılıma sahiptir?

2. HFACS yöntemi Ro-Ro tipi yük tașıyan gemilerde insan hatalarının sebep olduğu kazaları sınıflandırmada kullanılmaya uygun bir yöntem midir? Ro-Ro tipi yük gemilerinde farklı HFACS kategorileri olușturulmasına intiyaç var mıdır?

Bu sebeple bu çalıșmada Ro-Ro yük gemilerinde insan hatalarının sebep olduğu kaza türlerinin tespiti ve bu kazaların sınıflandırılmasında HFACS yönteminin kullanıșlıı̆ıının tespiti amaçlanmıștır. Bu kapsamda Ro-Ro yük gemilerinde meydana gelen kazaların tutulduğu raporlar incelenmiș, özetlenmiș ve kazaya sebep insan faktörünün bulunduğu sebepler tespit edilmiștir. Bu sebepler odak grup görüșmesi ile daha yalınlaștırılarak, HFACS kategorileri ile uygun bir șekilde kodlanmıștır.

Çalıșmanın yapısı șu șekildedir. 2. bölümde HFACS ve gemi kazaları kapsamında gerçekleștirilen çalıșmalar incelenmiș, 3. bölümde çalıșmanın materyal ve yöntemi anlatılmıș, 4. bölümde bulgular ve tartıșmaya yer verilmiș, 5 . bölümde ise sonuçlar özetlenmiștir.

\section{HFACS ve Gemi Kazaları}

Gemi kazaları literatürde oldukça geniș bir yer bulan bir konudur. Bu durumun sebepleri arasında deniz tașımacılığının ulaștırma modları arasında ve uluslararası ticarette oldukça fazla kullanılması ve deniz ticaretinde verimlilik ve etkililik konularının denizde emniyet ile doğrudan ilișkili olması olarak 
değerlendirilebilir (Uğurlu ve ark., 2020). HFACS yöntemi ise deniz kazalarının analiz edilmesinde oldukça tercih edilen bir yöntem olarak literatürde sıklıkla ele alınmıștır. Genel olarak HFACS yöntemi, kaza incelemelerinde insan hatalarını sınıflandıran ve böylelikle istatistiksel olarak insan hatası kaynaklı kaza sebeplerini ortaya koymaya yarayan bir yöntemdir (Wiegmann ve Shappell, 2003).

Halihazırda kaza sınıflaması için kullanılan HFACS yöntemini deniz kazalarına konu olan gemi türünün analizine uygun bir șekilde geliștiren çalıșmalar bulunmaktadır. Örneğin, Mazaheri ve ark. (2015) gemi kazalarının analiz edilebilmesinde kaza raporlarının kullanılabilirliğini analiz etmiș, mevcut HFACS kategorilerine "emniyet faktörleri" ekleyerek HFACS için yeni bir versiyon önermiștir. Uğurlu ve ark. (2018) yolcu gemilerinde meydana gelen kazaları HFACS yöntemi ile analiz etmiș ve yolcu gemilerinde uygulamak üzere HFACS-PV yaklașımını önermișlerdir. Wei ve ark. (2015) ise HFACS yöntemini bilișsel haritalama tekniği ile ilișkilendirmiștir. Bununla birlikte deniz kazalarının analizinde hibrit yaklașımları kullanan çalıșmalar da bulunmaktadır. Örneğin, Qiao ve ark. (2020) HFACS ve ișletme süreç yönetimi yaklașımlarını birbirleri ile entegre ederek MAMAC (Multi Dimensional Analysis of Accident Causes) olarak önerdiği bir yöntem ile analiz etmiștir. Akyuz ve Celik (2014) ise HFACS ve bilișsel haritalandırma yöntemlerini entegre ederek yolcu gemilerinde meydana gelen kazaları operasyonel koșulları dikkate alarak incelemișlerdir. Sarıalioğlu ve ark. (2020) HFACS ve bulanık hata ağacı analizini kullanarak patlama-yangın kazalarının genellikle 20 yașın üzerinde olan gemilerde meydana geldiği mekanik arızaların kaza olușumuna sebebiyet verdiğini tespit etmișlerdir. Hasanspahić ve ark. (2021) HFACS aracılığıyla gemi kazalarını incelemiș, bu kazaların olușmasına sebep olan faktörleri ve kazaya sebebiyet en fazla sebep olan etmenleri çoklu lineer regresyon ile analiz etmiștir. Kaptan ve ark. (2021) köprüüstü elektronik seyir cihazlarının kullanımıyla ilișkili insan faktörüne bağlı hataların karaya oturma ve çatıșma kazalarına etkisi araștırmıștır. İncelen gemi kazaları HFACS yöntemi ile incelenerek, Bayes ağları yöntemi ile kaza sebepleri arasında nedensellik ilișkisi tespit edilmiștir.

\section{Materyal ve Yöntem}

Bu çalıșmada, Ro-Ro tipi gemilerde gerçekleșen kazalar HFACS yöntemi ile incelenmiștir. Araștırmanın metodolojik süreci Șekil 1'de gösterilmektedir.

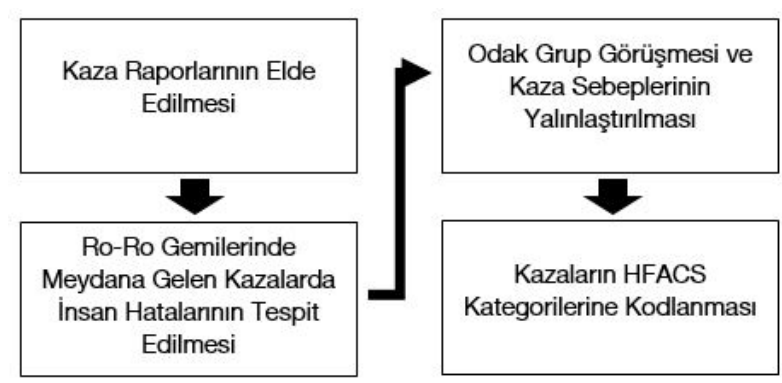

Șekil 1. Araștırma süreci diyagramı

\section{Ro-Ro Gemi Kaza Analizi}

Kaza raporları Küresel Bütünleșik Denizcilik Bilgi Sistemi (Global Integrated Shipping Information System-GSIS)'nin web kayıtlarından alınmıștır (IMO, 2020; GSIS, 2020). 30 tane kazaya ait rapor 1500 sayfadan olușmaktadır. Her bir rapor detaylıca analiz edilmiș, kaza raporları özetlenerek meydana gelen kazalarda insan faktörleri yargısal olarak tespit edilmiștir. Ro-Ro gemilerinde meydana gelen kazalardaki insan faktörleri Tablo 1'de gösterilmiștir. Tablo 1 'de belirtilen kaza sebeplerinin HFACS kategorilerinde sınıflandırılabilmesi ve mevcut HFACS düzey ve kategorilerinin belirtilen kaza sebeplerine uygunluğunun tartıșılabilmesi için odak grup çalıșması gerçekleștirilmesi gerekmektedir.

\section{Odak Grup Görüșmesi ve Kazaların HFACS Yöntemi ile Sınıflandırılması}

Analiz sonucu elde edilen Ro-Ro gemilerinde kazaya sebebiyet veren insan faktörleri, sektör temsilcileri ile odak grup görüșmesi gerçekleștirilerek yalınlaștırımıș ve HFACS kategorilerinde kodlanmıștır. Odak grup oturumu 6 saat sürmüștür. Çalıșmaya katılan sektör temsilcilerine ait profil Tablo 2'de gösterilmiștir.

Deniz kazalarının incelenmesinde birçok yöntem kullanılmaktadır. Bunlar temel olarak ardıșık yöntemler, sistematik yöntemler ve epidemiyolojik yöntemler olarak 3'e ayrılmaktadır (Hollnagel, 2002; Hollnagel ve ark., 2006). Bu çalıșmada epidemiyolojik bir yöntem olan HFACS Yöntemi kullanılmıștır. Epidemiyolojik yöntemlere göre, kazaların meydana gelmesi bir dizi olayın sonucudur ve bu olaylar aslında dikkatten kaçabilecek gizli hatalardan ortaya çıkmaktadır. Gizli hatalara yorgunluk, dalgınlık gibi etkenler örnek verilebilir. Gizli hatalar silsilesi sonucunda aktif hatalar meydana gelir. Bunlar ise emniyetsiz eylemler ve bunları hazırlayan alt nedenlerdir (Taylor ve ark., 2004; Yıldırım, 2016).

HFACS yönteminin esasında ilk kullanıldığı alan havacılık sektörüdür. Hava ulașımında yașanan 
Tablo 1. Elde edilen raporlarda belirlenen insan faktörünün sebep olduğu kaza sebepleri

\begin{tabular}{|c|c|}
\hline Sıra & Kaza Sebebi \\
\hline 1 & Hava muhalefeti sebebiyle görüșün kısıtlanması \\
\hline 2 & Köprüüstü Kaynak Yönetimine uygun olmayan davranıș \\
\hline 3 & $\begin{array}{l}\text { Vardiya zabitinin köprüüstü seyir cihazlarını etkili } \\
\text { kullanamaması }\end{array}$ \\
\hline 4 & $\begin{array}{l}\text { Denizde Çatıșmayı Önleme Tüzüğü' ne uygun olmayan } \\
\text { davranıș }\end{array}$ \\
\hline 5 & $\begin{array}{l}\text { Algilama hatası sebebiyle durumun farkına varama- } \\
\text { mak }\end{array}$ \\
\hline 6 & $\begin{array}{l}\text { Gemi Adamlarının Eğitim, Belgelendirme ve Vardiya } \\
\text { Tutma Standartları (Standards of Training Certifica- } \\
\text { tion and Watchkeeping-STCW)'na uygun bir șekilde } \\
\text { köprüüstü vardiya düzenlemesi yapılmaması }\end{array}$ \\
\hline 7 & Gemiler arası iletișimin yapılmaması \\
\hline 8 & Rota değișiminin gerekli șekilde yapılmaması \\
\hline 9 & $\begin{array}{l}\text { Çift dümenli geminin sancak taraf dümeninin olmadığı } \\
\text { bilindiği halde seyir yapılıması }\end{array}$ \\
\hline 10 & ISM evraklarının düzenli bir șekilde doldurulmaması \\
\hline 11 & $\begin{array}{l}\text { Șirketin gemi denetimlerini belirlenen takvim süresin- } \\
\text { ce yapmaması }\end{array}$ \\
\hline 12 & Hava muhalefeti durumunda römorkör alınmaması \\
\hline 13 & $\begin{array}{l}\text { Manevra esnasında gemi içinde düzgün iletișimin } \\
\text { sağlanamaması }\end{array}$ \\
\hline 14 & $\begin{array}{l}\text { Kaptanın pilotaj sınırları içinde gemi kumandasını } \\
\text { birinci zabite bırakması }\end{array}$ \\
\hline 22 & Dar kanal içinde emniyetli hızla seyir yapılmaması \\
\hline 23 & $\begin{array}{l}\text { Manevra esnasında römorkörlerin etkin șekilde } \\
\text { kullanılmaması }\end{array}$ \\
\hline 24 & $\begin{array}{l}\text { Kaptan ile kılavuz kaptan arasında bilgi değișiminin } \\
\text { eksik yapılması }\end{array}$ \\
\hline 25 & Köprüüstü e makine dairesi \\
\hline 26 & $\begin{array}{l}\text { Su almaya bașlayan gemide suyun tahliye edilmeye } \\
\text { bașlanmaması }\end{array}$ \\
\hline 27 & Çalıșmayan köprüüstü haberleșme cihazı \\
\hline 28 & $\begin{array}{l}\text { Kaptanın yerine birini atamadan köprüüstünü terk } \\
\text { etmesi }\end{array}$ \\
\hline 29 & Acil durumda gerekli alarmın verilmemesi \\
\hline 30 & Gemi terk durumunda uygunsuz tarafın seçilmesi \\
\hline 31 & Çatıșma durumunda kaptana geç haber verilmesi \\
\hline 32 & Eksik veya uygunsuz ekipman ile iș yapılması \\
\hline 33 & Vardiya mühendisinin makine dairesini terk etmesi \\
\hline 34 & Gemi dizaynının eksik veya hatalı olması \\
\hline 35 & $\begin{array}{l}\text { Rihtım bağlama ekipmanlarının eksik veya hatalı } \\
\text { olması }\end{array}$ \\
\hline 36 & $\begin{array}{l}\text { KIlavuz Kaptan gerekli eğitimleri tamamlamadan } \\
\text { göreve bașlamıș }\end{array}$ \\
\hline 37 & $\begin{array}{l}\text { Gemi stabilite kitabının klas tarafından onaylı olma- } \\
\text { ması }\end{array}$ \\
\hline 38 & Gemi planlarının eksik veya hatalı olması \\
\hline 39 & Planlı bakım tutum sisteminin eksik veya hatalı olması \\
\hline 40 & $\begin{array}{l}\text { Değișken adım pervane (Controllable Pitch Propel- } \\
\text { ler-CPP)'nin bozuk olması }\end{array}$ \\
\hline 41 & $\begin{array}{l}\text { Gemi emniyet ekipmanlarının yetersiz veya eksik } \\
\text { olması }\end{array}$ \\
\hline
\end{tabular}

Tablo 2. Katılımcı profili

\begin{tabular}{lccc}
\hline Ünvan & $\begin{array}{c}\text { Mezuniyet } \\
\text { Yllı }\end{array}$ & $\begin{array}{c}\text { Sektördeki } \\
\text { Tecrübe }\end{array}$ & Yaș \\
\hline Uzakyol Kaptan & 2003 & $18 \mathrm{yll}$ & 43 \\
/Akademisyen & & & \\
Uzakyol Kaptan & 2003 & $18 \mathrm{yll}$ & 42 \\
$\begin{array}{l}\text { Uzakyol Kaptan } \\
\text { Uzakyol Kaptan }\end{array}$ & 2007 & $14 \mathrm{yll}$ & 38 \\
$\begin{array}{l}\text { /Akademisyen } \\
\text { Uzakyol 1. Zabit }\end{array}$ & 2010 & $11 \mathrm{yll}$ & 35 \\
$\begin{array}{l}\text { /Akademisyen } \\
\begin{array}{l}\text { Uzakyol Vardiya Mühendisi } \\
\text { /Akademisyen }\end{array}\end{array}$ & 2011 & $10 \mathrm{yll}$ & 34 \\
\hline
\end{tabular}

uçak kazalarının incelenmesi ve kaza nedenlerinin tespit edilmesi amacıyla kategoriler olușturularak ortaya çıkarımıștır. Temel haliyle HFACS 4 satır ve 4 kategoriden olușmaktadır. Bunlar "Kurumsal Etkiler, Emniyetsiz Yönetim, Emniyetsiz Eylemi Hazırlayan Alt Nedenler ve Emniyetsiz Eylemler" dir. (Yıldırım, 2016; Dönmez ve Uslu, 2018). Deniz kazalarına uyarlanmıș HFACS versiyonunda ise bu kategoriler arasında (Șekil 2) dıș faktörler; yasalar, mevzuatlar, dizayn kusurları, idarenin, liman otoritelerinin hataları ve diğer alt kategorilerini içerirken yasalar ve mevzuatlar denizcilikle ilgili tüm yazilı kurallarla ilgili kanunlar veya yönetmeliklerdeki boșluklardan kaynaklı unsurları ifade etmektedir (Wei ve ark., 2015; Chen, 2020). Dizayn kusurları, geminin dizaynı ve ekipmanı ile ilgili probleme yol açabilecek ve emniyeti tehdit edebilecek eksikler, hataları ifade etmektedir. Idarenin, liman otoritelerinin hataları, liman ve yetkili otoritelerin uyulması gereken kuralları yerine getirmemesi ya da bu kurallara uyulmasında ortaya çıkan hataları ele alan unsurlar olarak nitelendirilir. Diğer hatalar ise kaza sebebi olabilecek diğer dıș faktörler olup, yukarıda açıklanan kategorilere girmeyen unsurlardır. Bir diğer kategori kurumsal etkilerdir ve kaynak yönetimi, kurumsal ortam ve kurumsal süreç alt kategorilerini içermektedir. Kaynak yöntemi, ișletme kendi iç yönetimi ile ilgili olup, bunlar insan kaynakları, bütçe kaynakları, ekipman kaynakları gibi tüm kaynakların yöntemini ifade etmektedir. Kurumsal ortam, ișletmenin yönetim elemanlarını, vizyonu ve misyonunu, ortak kültürünü ifade etmektedir. Burada ișletmenin alt üst ilișkilerini, șirket içi iletișim kalitesini, sorumluluklar, resmi yükümlülüklerini etkileyen faktörler düșünülebilir. Diğer taraftan kurumsal süreç, standartlara uyulması, prosedürlerin doğru uygulanması ve bireysel performansın arttırılması gibi unsurları kapsar. Ayrıca Emniyetli Yönetim Sistemi (SMS) kurallarına uyulmamasından doğan hatalar da bu kategoride değerlendirilir. Emniyetsiz yönetim, yetersiz yönetim, uygunsuz 
iș planlaması, bilinen problemi düzeltmeme ve yönetimin ihlalleri alt kategorilerden olușmaktadır. İs planı yapılırken prosedür ve kurallara uyulması önem arz etmektedir (Chauvin ve ark., 2013). Kural dıșı iș planı ancak acil durumlarda göz ardı edilebilir. Bunun dıșında kabul edilemez bir hatadır. Örneğin, çalıșanlara ekstra vardiya yaptırma ya da görevi dıșında bașka iș verme gibi hatalar uygunsuz iș planlaması kapsamında değerlendirilmektedir. Bilinen problemi düzeltmeme, geminin donanımı/ ekipmanı ile ilgili arıza durumları ya da eğitim, sertifika eksiklikleri gibi durumların bilindiği halde üstü örtülmesi ve giderilmemesi konularını kapsamaktadır. Yönetimin inlalleri ise uyulması gereken kuralların, yönetmeliklerin ya da talimatların yönetimin bilgisi ve inisiyatifi dahilinde uyulmaması durumudur. Emniyetsiz eylemi hazırlayan alt nedenler çevresel faktörler, bireyin durumu ve personel faktörleridir. Çevresel faktörler, fiziksel ve teknolojik çevre olarak ikiye ayrilır. Bireyin durumu, olumsuz ruhsal ve fiziksel durumlardan veya fiziksel ve zihinsel sınırlamalardan kaynaklanmaktadır. Personel faktörleri ise göreve hazır olma, gemiler arası/ gemi trafik sistemi (Vessel Traffic System-VTS) iletișimi ve kaynak yönetiminden olușmaktadır. Fiziksel çevre, meteorolojik koșullar ve deniz koșulları gibi çevresel faktörlerden ileri gelen durumları ifade eder. Teknolojik çevre, köprü üstü cihazlarının durumu gibi tüm teknolojik ekipmanın düzgün çalıșıp çalıșmaması ya da yeterli gelip gelmemesinden kaynaklanan etkenlerdir. Olumsuz ruhsal durum odaklanma sorunu, dikkat eksikliği, psikolojik sorunlar ya da yorgunluk gibi etkilerden kaynaklı performanstaki düșüklük sebebiyle ortaya çıkan durumlardır. Olumsuz fiziksel durum, herhangi bir fiziksel eksiklikten kaynaklı ișin düzgün yapılamaması durumundan doğacak sorunları ifade ederken, fiziksel/zihinsel sınılamalar, fiziksel ya da zihinsel eksikliklerden dolayı kısıtlı beceriye sahip olunmasından doğan sorunlar olarak nitelendirilir. Göreve hazır olma, kișinin sorumluluğunda olan iși emniyetli ve doğru bir șekilde yerine getirebilme yetisinden yoksun olduğu ve aldığı eğitimin gereğini yetiremediği durumdan doğan sorunlar olarak tanımlanmaktadır. Ayrıca kișinin kendinden kaynaklı diğer (uykusuzluk, alkol/uyușturucu ya da ilaç kullanımı vb.) durumlarından doğan bașarısızlık durumları bu bașlıkta değerlendirilmektedir. Gemiler arası/ VTS iletișimi, gemilerin birbirleriyle ya da VTS ile olan iletișim hatalarından kaynaklı doğan durumlar olarak tanımlanır. Kaynak yönetimi kategorisinde değerlendirilen sebepler tüm kaynakların doğru bir șekilde yönetilememesi durumundan ileri gelen sorunları kapsamaktadır. Bunlara köprü üstü kaynakları (elektronik ekipmanlar, personel, haritalar, sefer planları, uygulanacak prosedürlere ait dosyalar, evraklar vb.) ve makine dairesi kaynakları dahildir. Emniyetsiz eylemler kategorisi, emniyetsiz yönetim ve ihlaller olarak alt kategorilere ayrılmıștır. Emniyetsiz yönetim karar, beceri ve algılama hataları olarak açıklanmaktadır. İhlaller ise, rutin ve istisnai ihlallerdir (Yıldız, 2016; Uğurlu ve ark., 2018). Diğer taraftan karar hataları, kritik bir olay anında ya da operasyonu direk etkileyecek bir karar așamasında verilen kararın yanlıș olması ve olumsuz sonuçlar doğurması durumudur. Genellikle bilgi eksikliği ve tecrübesizlik kaynaklı olmasının yanında kriz yönetimi yapamama ya da stres gibi faktörlere de bağlıdır. En yaygın yapılan hatalardır. Beceri hataları ise yapılan ișe yetememe, beceri olarak yetersiz olma durumundan çıkan hatalardır. Algılama hataları: yetersiz algılama sonucu yanlıș anlașılmadan kaynaklı ortaya çıkan hatalardır. Bununla birlikte rutin ihlaller standart ve kurallara uyulmamasından kaynaklı inlallerdir. İșleyiși kolaylaștırmak amacıyla bazı kuralların atlanması durumudur. Yönetim tarafından bilinmektedir ve çoğunlukla göz ardı edilebilir ihlalleri kapsamaktadır. Son olarak istisnai ihlaller yazılı olan kurallar haricinde uyulması gereken kuralların göz ardı edilmesidir. Bunlar gemi yönetimi tarafından kabul edilmeyen inlallerdir (Yıldırım, 2016).

\section{Bulgular ve Tartıșma}

Bu çalıșmada Ro-Ro gemilerinde meydana gelmiș 30 farklı kazaya ait raporlar incelenmiștir. Elde edilen kazaya sebep olan 41 adet insan faktörü, 6 uzman kișinin bir araya geldiği bir odak grup görüșmesinde değerlendirilmiș ve HFACS kategorilerine göre kodlanmıștır. Odak grup görüșmesi yaklașık 5 saat sürmüș, kaza sebeplerinin analizine bașlamadan önce katılımcılara HFACS yaklașımı, deniz kazalarının sınıflandırılmasındaki rolü anlatılmıștır. Katılımcıların yöntem konusunda yeterli bilgi seviyesine sahip olduğuna emin olunduktan sonra tartıșmaya geçilmiștir. Odak grup sonucunda 41 adet belirlenen insan hataları 23 farklı ana sebep olarak revize edilmiștir. Bu sebepler Tablo 3'te gösterilmiștir.

Nihai olarak elde edilen kaza sebeplerinin HFACS kategorilerine uygunluğu tartıșılarak, belirlenen kaza sebepleri eș zamanlı olarak HFACS alt kategorilerinden uygun olanlara yerleștirilmiș ve sayıları kodlama tablosunda gösterilmiștir (Tablo 4). Deniz kazalarına uyarlanmıș HFACS kategorilerini insan hataları ve dıș faktörler olarak iki kısma ayırmak mümkündür. Buna göre kodlanmıș kazalardan elde edilen sonuçların 


\begin{tabular}{|l|l|}
\hline No & Kaza Sebebi \\
\hline KS1 & Vardiya zabitinin gerekli durumda kaptana haber vermemesi \\
\hline KS2 & Vardiya zabitinin köprü üstü cihazlarını etkili bir șekilde kullanamaması \\
\hline KS3 & Denizde Çatıșmayı Önleme Tüzüğü' ne uygun olmayan șekilde davranııması \\
\hline KS4 & Bilgi eksikliğine bağlı olarak amaçlanan faaliyeti yerine getirememek \\
\hline KS5 & Uygun olmayan șekilde vardiya düzenlemesi yapııması \\
\hline KS6 & Algılama hatası sebebiyle durumun farkına varamamak \\
\hline KS7 & Gemiler arası haberleșmenin yapılamaması \\
\hline KS8 & Gemi içerisinde iletișim sağlanamaması \\
\hline KS9 & Personelin görev bilincine uygun șekilde davranmaması \\
\hline KS10 & ISM kapsamında yapııması gereken kontrollerin yapıımaması \\
\hline KS11 & Kaptan ile kılavuz kaptan arasında bilgi değișiminin eksik veya hatalı yapılması \\
\hline KS12 & Römorkörlerin etkin bir șekilde kullanılmaması \\
\hline KS13 & Acil durumda gerekli prosedürün uygulanmaması \\
\hline KS14 & Uygunsuz veya eksik ekipmanla iș yapııması \\
\hline KS15 & Donanımsal ve ekipman arızaları bilindiği halde düzeltilmemesi \\
\hline KS16 & Sefer planın eksik veya hatalı olarak hazırlanması \\
\hline KS17 & Șirketin gemi denetimindeki görevlerini aksatması \\
\hline KS18 & Planlı bakım sisteminin eksik veya hatalı olması \\
\hline KS19 & Personelin gemiyi yeterince tanımaması \\
\hline KS20 & Ticari sebepler ile gemi emniyetinin göz ardı edilmesi \\
\hline KS21 & Șirket tarafından personele yeterli eğitimin verilmemesi \\
\hline KS22 & Eksik ya da hatalı malzeme ikmal edilmesi \\
\hline KS23 & Gemi șirket arasında yașanan otorite problemi \\
\hline & \\
\hline
\end{tabular}

Tablo 3. Odak grup görüșmesi sonucu elde edilen bulgular
Șekil 2. Deniz kazalarına uyarlanmıș kategorileri

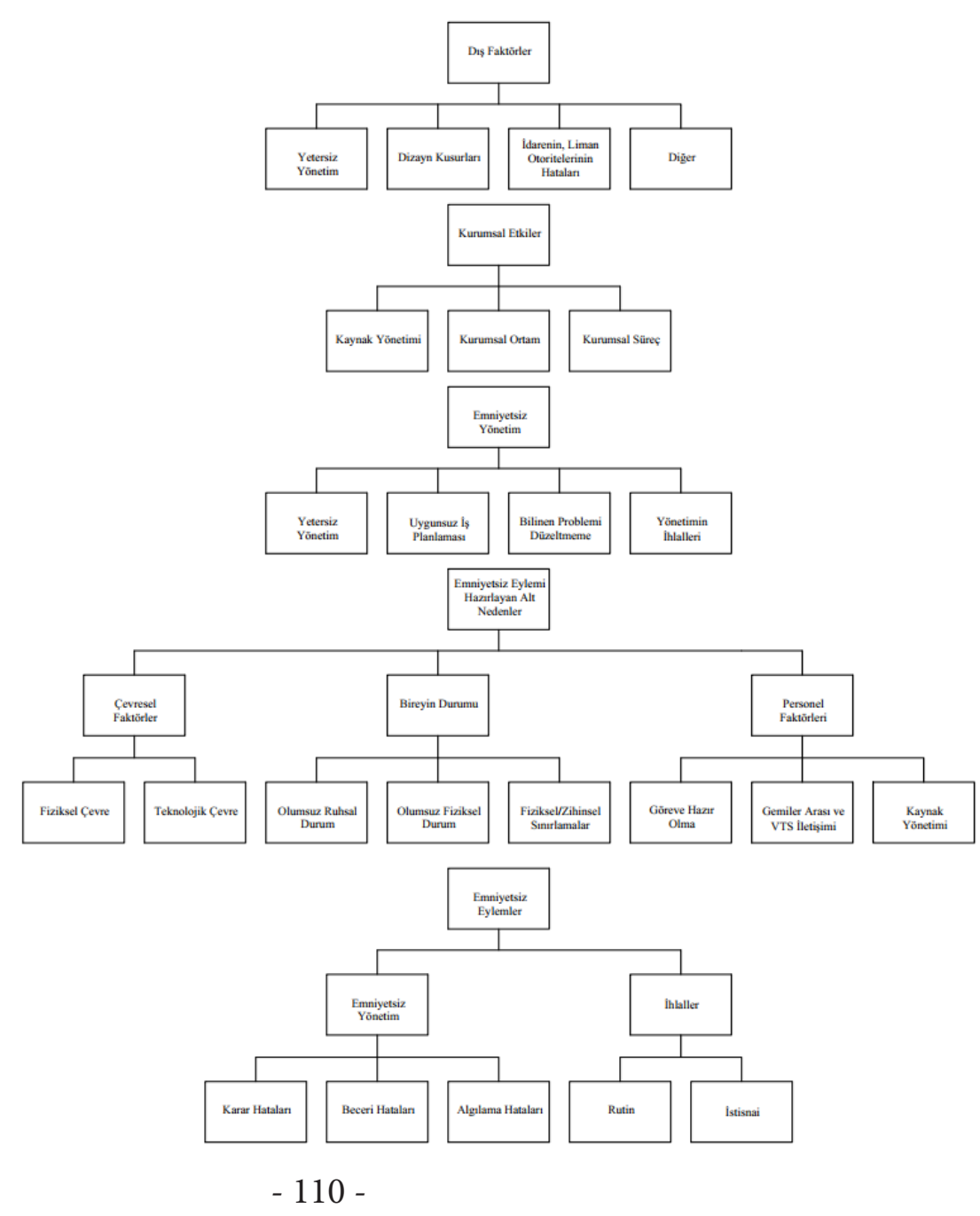


Tablo 4. Ro-Ro gemilerinde meydana gelen insan faktörlü kazaların HFACS düzeyleri ve kategorileri arasında dağılımı

\begin{tabular}{|c|c|c|c|c|c|c|c|c|c|c|c|c|c|c|c|c|c|c|c|c|c|c|c|c|c|c|c|c|}
\hline & 1 & 2 & 3 & 4 & 5 & 6 & 7 & 8 & 9 & & 11 & 12 & 13 & 14 & 15 & 16 & & & 920 & 21 & 222 & 2324 & & 262 & & 29 & 30 & Toplan \\
\hline \multicolumn{29}{|l|}{ DIȘ FAKTÖRLER } \\
\hline \multicolumn{29}{|l|}{ Yasalar, Mevzuat } \\
\hline Dizayn Kusurları & & & & & & & & & & & & & & 2 & 1 & & & 1 & 1 & & & & & & & & & 4 \\
\hline \multicolumn{29}{|l|}{ İdarenin, Liman } \\
\hline Otoritelerinin Hataları & & & & & & & & & & & & & & 1 & 3 & & & 11 & 1 & & & & & & 2 & & 1 & 9 \\
\hline Diğer & & & & & & & & & & & & & & & & & & & & & & 1 & 1 & & & & & 1 \\
\hline \multicolumn{29}{|l|}{ KURUMSAL ETKILER } \\
\hline Kaynak Yönetimi & & & & 1 & & & & & & & & & & & & 4 & & & & & & & & & 1 & & & 6 \\
\hline \multicolumn{29}{|l|}{ Kurumsal Ortam } \\
\hline \multicolumn{29}{|l|}{ EMNIYETSIZ YÖNETIM } \\
\hline Yetersiz Yönetim & & & & & & & & & & & & & & & & & & & & & & & & & & & & $\mathbf{0}$ \\
\hline Uygunsuz İș Planlaması & & & & & & & 2 & & & & & & & & & & & & & 1 & & & & & 1 & & & 4 \\
\hline \multicolumn{29}{|l|}{ Bilinen Problemi } \\
\hline Düzeltmeme & & & 1 & & & & & & & 2 & & & 2 & & 4 & & & 1 & 11 & & & & 1 & & 1 & & & 13 \\
\hline Yönetimin İhlalleri & & & & & & & & & & & & & & & & & & & 1 & & & & & & & & & 1 \\
\hline \multicolumn{29}{|c|}{$\begin{array}{l}\text { EMNIYETSIZ EYLEMLERI HAZIR- } \\
\text { LAYAN ALT NEDENLER }\end{array}$} \\
\hline \multicolumn{29}{|l|}{ Çevresel Faktörler } \\
\hline Fiziksel Çevre & 1 & & & & & & & & & & & & & & & & & & & & & & & & & & & 1 \\
\hline Teknolojik Çevre & 1 & & & & & 1 & & & & 2 & & & & & & & & & & 2 & & & & & & & & 6 \\
\hline \multicolumn{29}{|l|}{ Bireyin Durumu } \\
\hline Olumsuz Ruhsal Durum & & & & & & & & & & 2 & & & & & & 1 & 2 & 5 & & & & & & & & & & \\
\hline \multicolumn{29}{|l|}{ Olumsuz Fiziksel Durum } \\
\hline \multicolumn{29}{|l|}{ Fiziksel/Zihinsel } \\
\hline \multicolumn{29}{|l|}{ Sınırlamalar } \\
\hline \multicolumn{29}{|l|}{ Personel Faktörleri } \\
\hline \multicolumn{29}{|l|}{ Göreve Hazır Olma } \\
\hline Gemiler Arası ve VTS & & & & & & & & & & & & & & & & & & & & & & & & & & & & \\
\hline İletișimi & & & 1 & & & 1 & & & & 1 & & 2 & & & & & & 1 & 1 & 1 & & & & & 1 & & & 8 \\
\hline Kaynak Yönetimi & 1 & & 1 & 1 & 1 & 1 & & & 3 & 1 & 3 & & 3 & 1 & & & 1 & 11 & 12 & 2 & 22 & 21 & 11 & & & 1 & 1 & 31 \\
\hline EMNIYETSIZ EYLEMLER & & & & & & & & & & & & & & & & & & & & & & & & & & & & \\
\hline Hatalar & & & & & & & & & & & & & & & & & & & & & & & & & & & & \\
\hline Karar Hataları & & & 1 & 1 & & 1 & & 1 & 2 & & 2 & & & & 2 & & & & & & 21 & 1 & & & 1 & & & 14 \\
\hline Beceri Hataları & & & & & & & & & 1 & & & & & & & 3 & & & & & & & & 2 & & & & 6 \\
\hline Algılama Hataları & & 1 & & 1 & & & & 1 & & & & & & & 1 & & 1 & & & 1 & 2 & & & & & & 1 & 9 \\
\hline İhlaller & & & & & & & & & & & & & & & & & & & & & & & & & & & & \\
\hline Rutin & 3 & 4 & 2 & & & 4 & 1 & 1 & 4 & 3 & & 2 & 2 & & 1 & 2 & 2 & 96 & 62 & 4 & 23 & 33 & 34 & 22 & 21 & 5 & 5 & 79 \\
\hline İstisnai & & & & 4 & & & & & & & 1 & & 3 & & & & & 3 & & & & & & & & & & 11 \\
\hline Toplam & 6 & 5 & 5 & 9 & 1 & 8 & 3 & 3 & 10 & 7 & 8 & 4 & 8 & 6 & 8 & 13 & 4 & 1610 & 106 & 12 & 86 & $\begin{array}{ll}65 \\
\end{array}$ & 5 & 53 & 38 & 6 & 10 & 208 \\
\hline
\end{tabular}

dıș faktörler kategorilerine giren hata oranı ve diğer kategorilere giren hata oranı hesaplanarak insan hatası yüzdesi elde edilebilmektedir. Tablo 4'e göre toplamda 208 hataya rastlanmıștır. Bu hataların 14 tanesi dıș faktörlerden kaynaklı olup, 194 tanesi insan hatası kaynaklı olarak belirlenmiștir. Bunun yanı sıra, insan kaynaklı hataların içinde "Kurumsal Etkiler" den kaynaklı hataların sayısı 6, "Emniyetsiz Yönetim" den kaynaklı hataların sayısı 18, "Emniyetsiz Eylemi Hazırlan Alt Nedenler" den kaynaklı hataların sayısı 51 ve "Emniyetsiz Eylemler" den kaynaklı hataların sayısı ise 119 bulunmuștur. Yukarıda belirtilen veriler doğrultusunda Ro-Ro gemilerinde insan faktörünün bulunduğu temel düzeylere ait dağılımlar Șekil 3'te belirtilmiștir.

Elde edilen veriler doğrultusunda Ro-Ro gemilerinde meydana gelen kazaların yalnızca 
6,73'lük bir kısmının "Dıș Faktörler" den kaynaklı olduğu tespit edilmiștir. \%93,27 ise insan hatalarından kaynaklanan kazalardır. Yapılan benzer çalıșmalar da gemi kazalarının büyük çoğunluğunun gemi tipinden bağımsız olarak insan hatalarından kaynaklandığını göstermektedir (Baker ve McCafferty; 2005; Saatcioglu vd., 2007; Wang ve ark., 2013; Chauvin ve ark., 2013; Chen ve ark., 2013; Batalden ve Sydnes, 2014; Uğurlu ve ark., 2015; Eliopoulou ve ark.; 2016; Chen, 2020; Hasanspahić ve ark., 2021).

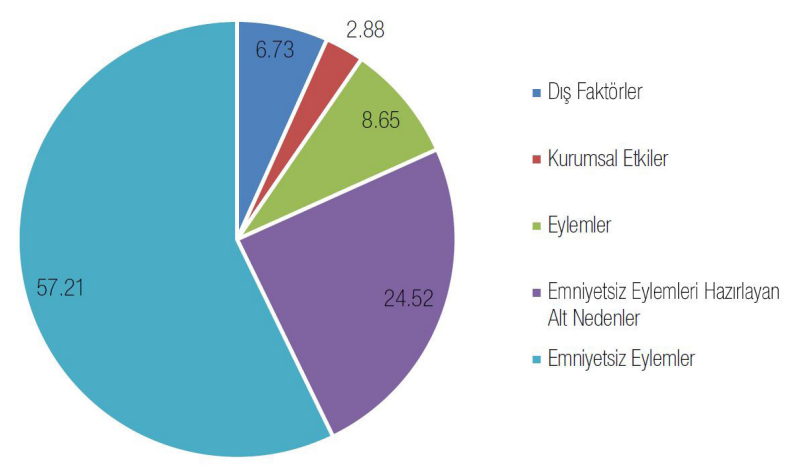

Șekil 3. HFACS düzeylerinde kaza sebepleri dağılımları

HFACS düzeyleri arasında insan faktörünün en fazla kazaya sebep olduğu kategori "Emniyetsiz Eylemler"dir. Kaza kategorileri arasında ikinci en büyük oran ise "Emniyetsiz Eylemleri Hazırlayan Alt Nedenler" kategorisinde yer almaktadır. 6,73'lük dilimle "Dıș Faktörler" bulunmakta iken en düșük oran 2,88 ile "Kurumsal Etkiler" kategorisine aittir. Kaza sebepleri dikkate alındığında RoRo gemilerinde meydana gelen kazalarda kurumsal etkilerin diğer etkilere nazaran daha az olduğu dikkat çekmektedir. Literatürdeki benzer çalıșmaların sonuçlarına bakıldığında Yıldııım, (2016) deniz kazaları ve Yıldız, (2016) ise yolcu gemisi kaza incelemelerinde HFACS kategorilerini deniz kazalarına uyarlayarak, kaza nedenlerini kodlamıș ve çalıșmalarında en çok gemi çatıșma ve karaya oturma kazalarının yașandığını tespit etmișlerdir. Yıldıım, (2006)' ın çalıșmasına göre, en önemli HFACS faktörü karar hatası, ihlal, beceri ve kaynak yönetimi olarak bulunmuștur. Yıldız, (2016)' a göre ise, en yüksek oran çevresel faktörlerdir. Chauvin ve ark., (2013)' ın çeșitli gemi türleri üzerinde yapmıș olduğu benzer çalıșmasında ise beceri hatalarının ön plana çıktığı, beceri hatalarının emniyetsiz eylemlerle ilgili olduğu ve emniyetsiz eylemler içinde \%85 oranında karar hataları, \%15 oranında ise algı hatalarından kaynaklandığı sonucu çıkarılmıștır.

Ro-Ro gemilerinde meydana gelen kazaların
HFACS kategorileri arasındaki dağılımı ise Șekil 4'te gösterilmektedir.
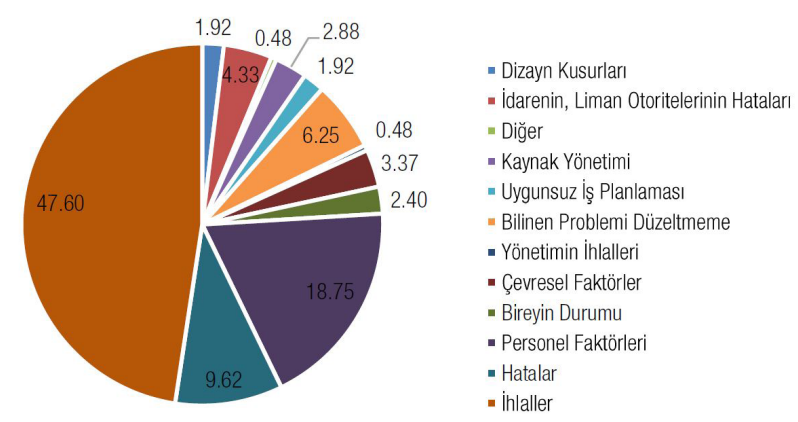

Șekil 4. HFACS kategorilerinde insan faktörlü kaza sebepleri dağılımları

HFACS kategorileri arasında kazaya sebebiyet veren etmenlerin arasında en fazla "ihlaller" olduğu tespit edilmiștir. Bu sonuç Akyuz ve Celik (2014) ve Qiao ve ark. (2020)'nin gerçekleștirmiș olduğu çalıșma ile benzerlik göstermektedir. İkinci olarak "Personel Faktörleri" yer almaktadır. 3. sırada ise 6,25 oranı ile "Bilinen Problemleri Düzeltmeme" kategorisi bulunmaktadır.

\section{Sonuç}

Ro-Ro gemi kazalarından elde edilen bilgiler dahilinde kazalara sebebiyet veren hatalar HFACS yöntemi ile kodlanmıștır. Sonuçlara göre 30 farkı kaza içinde insan hatası yüzdesinin \%93,27 olduğu tespit edilmiștir. Sonuçlar bu alanda gerçekleștirilen diğer çalıșmaların bulguları ile de örtüșmektedir (Baker ve McCafferty; 2005; Saatcioglu vd., 2007; Wang ve ark., 2013; Chauvin ve ark., 2013; Chen ve ark., 2013; Batalden ve Sydnes, 2014; Uğurlu ve ark., 2015; Eliopoulou ve ark.; 2016; Chen, 2020; Hasanspahić vd., 2021). Insan hataları içinde ise en yüksek oranla kazaya sebebiyet veren hataların emniyetsiz eylemlerden kaynaklandığıgörülmüștür. Emniyetsizeylemlerden kaynaklı hataların insan hataları içindeki yüzdesi \%61 civarındadır. Bunların içinde ise, en yüksek oranda olan insan hatası rutin ihlallerden kaynaklanmaktadır. Insan hataları içinde rutin inlallerden kaynaklı sorunların en bașta gelmesi konulan kurallara uyulmasının ne derecede önemli olduğunu ortaya koymaktadır. Gemi kazalarının maddi boyutlarının oldukça yüksek olmasının yanı sıra, yaralanma ve can kayıplarına yol açtığı aynı zamanda çevresel açıdan büyük zararlara sebebiyet verdiği de unutulmamalıdır. Bu sebeple denizde emniyeti sağlamaya yönelik konulmuș kurallara, ulusal düzenlemelere ve uluslararası sözleșmelere uyulmasının hayati önemi olduğu bir kez daha anlașılmaktadır. 
Bunların yanı sıra kazalara sebep olan etkenlerin arasında arızalar, aniden ortaya çıkan ve kontrol edilemeyen durumlar da rol oynamaktadır. Ancak bu durumların ortaya çıkmasında kök nedenlere inildiğinde büyük oranda insan hatalarının söz konusu olduğu ortaya konulmuștur. Bu gibi durumların önüne geçilmesi için de bakım tutum planına uygun davranılması, denetimlerin ve kontrollerin zamanında yapılması ve bu konuda bilincin arttırılması önerilmektedir (Yıldız, 2016; Yıldırım 2016). Ayrıca emniyetsiz durumların çoğunlukla kural ihlallerinden kaynaklandığı ve kurumsal güvenlik kültürünün olușturulmasında SMS, ISM gibi önemli gemi yönetim sistemlerinin önemi vurgulanmaktadır (Chauvin ve ark., 2013).

Yapılan bu çalıșmayla ile literatürde yapılmıș diğer benzer çalıșmaların sonuçlarının benzerlik gösterdiği, ancak Ro-Ro gemisi kazalarına özel bir kaza sebebinin olmadığı tespit edilmiștir. Kazaya sebep olan insan faktörleri ve Ro-Ro yük gemilerinde gerçekleșen kaza sebeplerinin genel kaza sebepleri ile uygunluk gösterdiği dikkate alındığında HFACS yönteminin bu kazaların sınıflandırılmasında kullanılabileceği sonucuna varılmıștır.

Sonraki çalıșmalar için ise deniz kazaları incelenirken gemi yașı, boyutu, personelin milliyeti ya da sefer sahasına göre gemiler bazında araștırmalar yapılarak insan faktörlerinin diğer etkenlerle ilișkisinin incelenmesi önerilmektedir.

\section{ETIKK STANDARTLARA UYUM}

\section{Yazarların Katkısı}

Tüm yazarların makaleye katkısı eșit orandadır.

\section{Çıkar Çatıșması}

Yazarlar herhangi bir çıkar çatıșması olmadığını deklare etmektedir.

\section{Etik Onay}

Yazarlar bu tür bir çalıșma için resmi etik kurul onayının gerekli olmadığını bildirmektedir.

\section{Kaynaklar}

Akyuz, E. \& Celik, M. (2014). Utilisation of cognitive map in modelling human error in marine accident analysis and prevention. Safety Science, 70: $19-28$. https://doi.org/10.1016/i.ssci.2014.05.004

Akyuz, E. (2015). A decision-making model proposal on human reliability analysis onboard ships, Ph.D. thesis, Istanbul Technical University-Graduate School of Science Engineering and Technology.

Arslan, Ö., Zorba, Y. \& Svetak, J.,(2018). Fault tree analysis of tanker accidents during loading and unloading operations at the tanker terminals. Journal of ETA Maritime Science, 6(1): 3-16. https://doi.org/10.5505/jems.2018.29981

Baker, C. C. \& McCafferty, D. B. (2005). Accident database review of human element concerns: What do the results mean for classification. In Proc. Int Conf.'Human Factors in Ship Design and Operation, RINA Feb.

Batalden, B. M. \& Sydnes, A. K. (2014). Maritime safety and the ISM Code: A study of investigated casualties and incidents. WMU Journal of Maritime Affairs, 13(1): 3-25. https://doi.org/10.1007/s13437-013-0051-8

Chauvin, C., Lardjane, S., Morel, G., Clostermann, J. P. \& Langard, B. (2013). Human and organisational factors in maritime accidents: analysis of collisions at sea using the HFACS. Accident Analysis \& Prevention, 59: 26-37. https://doi.org/10.1016/j.aap.2013.05.006

Chen, S. T., Wall, A., Davies, P., Yang, Z. L., Wang, J. \& Chou, Y. H. (2013). A human and organisational factors (HOFs) analysis method for marine casualties using HFACS maritime accidents (HFACS-MA), Safety Science, 60: 105-114. https://doi.org/10.1016/i.ssci.2013.06.009

Chen, J., Bian, W., Wan, Z., Yang, Z., Zheng, H. \& Wang, P. (2019). Identifying factors influencing total-loss marine accidents in the world: Analysis and evaluation based on ship types and sea regions. Ocean Engineering, 191: 106495. https://doi.org/10.1016/i.oceaneng.2019.106495

Chen, S. T. (2020). An approach of identifying the common human and organisational factors (HOFs) among a group of marine accidents using GRA and HFACS-MA. Journal of Transportation Safety \& Security, 12(10): 1252-1294. https://doi.org/10.1080/19439962.2019.1583297

Dönmez, K. \& Uslu, S. (2018). Evaluation of the widespread use of human factors analysis and classification system (HFACS) in literature. Journal of Aviation, 2(2): 156-176. https://doi.org/10.30518/jav.463607

Eliopoulou, E., Papanikolaou, A. \& Voulgarellis, M. (2016). Statistical analysis of ship accidents and review of safety level. Safety Science, 85: $282-292$. https://doi.org/10.1016/j.ssci.2016.02.001

GISIS, (2020). Global Intergrated Shipping Information System. Retrieved on January 06, 2020 from https://gisis.imo.org/Public/Default.aspx.

Hasanspahić, N., Vujičić, S., Frančić, V. \& Čampara, L. (2021). The role of the human factor in marine accidents. Journal of Marine Science and Engineering, 9(3): 1-16. https://doi.org/10.3390/jmse9030261

Hollnagel, E., (2002). Understanding accidents-from root causes to performance variability. IEEE, $7^{\text {th }}$, Human Factors Meeting Scottsdale, Arizona.

Hollnagel, E., Woods, D. D. \& Leveson, N. G. (2006). Resilience engineering: Concepts and precepts. Ashgate Publishing Company, Aldershot, Hampshire, England.

IMO, (2000). Revised harmonized reporting procedures - Reports required under SOLAS regulation I/21 and MARPOL 73/78. Articles 8 and 12, United Kingdom, MSCMEPC. 3/Circ.1(1): 1-47. 
IMO, (2020). International Mritime Organization. Retrieved on April 01, 2020 from https://gisis.imo.org/Public/MCI/Search.aspx GISIS: Marine Casualties and Incidents.

JTSB, (2020). Japan Transport Safety Board, Retrieved on April 01, 2020 from http://www.mlit.go.jp/itsb/Investigation Reports.html Investigation Reports.

Kaptan, M., Uğurlu, Ö. \& Wang, J. (2021). The effect of nonconformities encountered in the use of technology on the occurrence of collision, contact and grounding accidents. Reliability Engineering and System Safety, 215: 107886. https://doi.org/10.1016/j.ress.2021.107886

Mazaheri, A., Montewka, J., Nisula, J. \& Kujala, P. (2015). Usability of accident and incident reports for evidence-based risk modeling-A case study on ship grounding reports. Safety Science, 76: 202-214. https://doi.org/10.1016/j.ssci.2015.02.019

MSC-MEPC, (2000). Reports on Marine Casualties and Incidents, International Maritime Organization, 1-45.

Navas de Maya, B. \& Kurt, R. E. (2020). Marine accident learning with fuzzy cognitive maps (MALFCMs). MethodsX, 7: 100940. https://doi.org/10.1016/j. mex.2020.100940

Qiao, W., Liu, Y., Ma, X. \& Liu, Y. (2020). Human factors analysis for maritime accidents based on a dynamic fuzzy bayesian network. Risk Analysis, 40(5): 957-980. https://doi.org/10.1111/risa.13444

Saatçıoğlu, Ö. Y., Göksu, B., Yüksel, O. \& Gülmez, Y. (2017). Ship engine room casualty analysis by using decision tree method. Journal of ETA Maritime Science, 5(1), 59-68. https://doi.org/10.5505/jems.2017.27146

Sarıalioğlu, S., Uğurlu, Ö., Aydın, M., Vardar, B. \& Wang, J., (2020). A hybrid model for human-factor analysis of engine-room fires on ships: HFACS-PV\&FFTA. Ocean Engineering, 217: 107992. https://doi.org/10.1016/j.oceaneng.2020.107992

Taylor, G., Easter, K. \& Hegney, R. (2004). Enhancing occupational safety and health, Elsevier Butterworth-Heinemann, Great Britain.

TSB, (2020). Transportation Safety Board of Canada. Retrieved on April 01, 2020 from http://www.tsb.gc.ca/eng/qui-about/index.asp

Uğurlu, Ö., Yıldırım, U. \& Bașar, E. (2015). Analysis of grounding accidents caused by human error. Journal of Marine Science and Technology, 23(5): 748-760.https://doi.org/10.6119/JMST-015-0615-1

Uğurlu, Ö. (2016). Analysis of fire and explosion accidents occurring in tankers transporting hazardous cargoes. International Journal of Industrial Ergonomics, 55: 1-11. https://doi.org/10.1016/..ergon.2016.06.006

Uğurlu, Ö., Yıldız, S., Loughney, S. \& Wang, J. (2018). Modified human factor analysis and classification system for passenger vessel accidents (HFACS-PV). Ocean Engineering, 161: 47-61. https://doi.org/10.1016/j.oceaneng.2018.04.086

Wang, Y. F., Xie, M., Chin, K. S. \& Fu, X. J. (2013). Accident analysis model based on bayesian network and evidential reasoning approach, Journal of Loss Prevention in the Process Industries, 26(1): 10-21. https://doi.org/10.1016/j.jp.2012.08.001

Wei, X. Y., Wang, Y., Yan, X. P., Wu, B. \& Tian, Y. F. (2015). A human factors analysis method for marine accident Evolution using HFACS-El model. ASME $34^{\text {th }}$ International Conference on Offshore Mechanics and Arctic Engineering, 56550: V007T06A049. https://doi.org/10.1115/omae2015$\underline{41858}$

Wiegmann, D. \& Shappell, S. (2003). A human error approach to aviation accident analysis: The human factors analysis and classification system, Ashgate Press, Aldershot.

Yıldıım, U., (2016). Deniz kazalarının insan faktörleri analiz ve sınıflandırma sistemi (HFACS) ile incelenmesi. Doktora Tezi, Karadeniz Teknik Üniversitesi, Gemi İnșaatı ve Gemi Makineleri Mühendisliği, Trabzon/Türkiye.

YIIdz, S. (2016). Application of the sea traffic management (STM) concept for fishing vessels, Master's Thesis, Universitat Politècnica de Catalunya, Department of Nautical Engineering and Maritime Transport, Barcelona/Spain. 